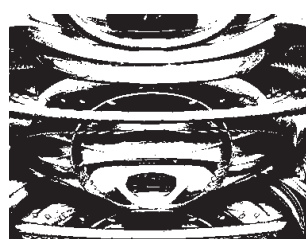

doi:10.5559/di.22.2.07

\title{
EFEKT NEPOVRATNOGA TROŠKA
}

Marko BOKULIĆ

Sveučilište u Regensburgu, Regensburg

Kosta BOVAN

Zagreb

UDK: 330.8:159.9.019.4

Pregledni rad

Primlieno: 3. 12. 2011.

Normativni principi u ekonomiii, opisani teorijom racionalnog izbora, pretpostavljaju da odluke donosimo isključivo na temelju budućih dobitaka i gubitaka. Međutim, rezultati niza istraživanja pokazali su kako na naše odluke utječu nepovratni troškovi, odnosno ulaganja iz prošlosti, ishod kojih se ne može promijeniti. Ova pojava poznata je pod nazivom efekt izgubljenoga troška (sunk cost effect) i očituje se kroz dva oblika. Dilema izbora želja je da pošto-poto iskoristimo ono što smo platili, a prilikom odlučivanja o nastavku ulaganja imamo tendenciju dodatno ulagati u projekt koji ide prema gubitku. U ovom radu opisana su oba oblika efekta izgublienoga troška i izneseni nalazi relevantnih istraživanja. Objašnjena je upotrijebljena metodologija i njezine kritike, a razmotrene su razlike između ekonomskih i psiholoških teoretskih objašnjenja. Na kraju rada navode se implikacije navedenih nalaza u rukovoditeljskoi praksi.

Ključne riječi: efekt nepovratnoga troška, dilema izbora, eskalacija predanosti, donošenje odluka i procjena, bihevioralna ekonomija

$\triangle \quad$ Marko Bokulić, Universität Regensburg, Universitätsstraße 31, 93053 Regensburg, Deutschland.

E-mail: Marko1.Bokulic@psychologie.uni-regensburg.de

\section{UVOD}

U ekonomskoj literaturi pojam nepovratnoga troška (eng. sunk cost) odnosi se na izgubljeno ulaganje, ishod kojega ne možemo promijeniti donošenjem odluka u sadašnjosti (Arnold, 2008). Takve troškove nalazimo i u poslovnom i u svakodnevnom kontekstu. Primjerice, novac koji neka tvrtka potroši na mar- 
DRUŠ. ISTRAŽ. ZAGREB GOD. 22 (2013), BR. 2, STR. $347-366$

BOKULIĆ, M., BOVAN, K. EFEKT NEPOVRATNOGA..

DILEMA IZBORA ketinšku kampanju nepovratan je, jer se takva kampanja (koja uključuje televizijske spotove, plakate itd.) ne može preprodati. Kupimo li sezonsku kazališnu kartu, taj je trošak nepovratan ako je ne možemo preprodati ili zamijeniti za nešto drugo. Zbog toga što na takve troškove ne možemo više utjecati ne treba nas čuditi da nam ekonomisti pružaju savjet da ih jednostavno treba zaboraviti i na njih više ne obraćati pozornost (Arnold, 2008). Naime, prema teoriji racionalnog izbora, ekonomskom standardu dobra odlučivanja, kada donosimo odluke, trebamo se orijentirati isključivo na buduće dobitke i gubitke (Thaler, 1980). Primjerice, ako imamo kartu za koncert do kojeg se moramo voziti dva sata po nevremenu, naša odluka treba se temeljiti samo na procjeni dobiti (koncert) i gubitaka (vožnja kroz oluju). Međutim, Richard Thaler (1985) pokazao je da ljudi u ovom slučaju svoju odluku temelje i na (nepovratnoj) cijeni karte. Njegovi su ispitanici izjavljivali da su spremniji otići na koncert kad im je bilo rečeno da su kartu platili nego kad im je bilo rečeno da su je dobili besplatno.

Skup pojava sličnih spomenutoj, u kojima na odluke o novčanim ulaganjima ili ulaganjima truda i vremena utječu i prijašnja ulaganja, zove se efekt nepovratnoga troška (eng. sunk cost effect; Arkes i Blumer, 1985). Efekt ima dva oblika - tzv. dilemu izbora i odluku o nastavku ulaganja. U ovom radu predstavit ćemo oba oblika, kao i nekoliko teorijskih rješenja za svaki od njih. Počet ćemo s dilemom izbora.

Dilema izbora odnosi se na situaciju u kojoj biramo koju od dvije ili više opcija želimo iskoristiti ili koju od aktivnosti želimo poduzeti. Efekt nepovratnoga troška u takvoj situaciji očituje se u želji da svakako iskoristimo ono što smo već platili, čak i ako takvo ponašanje uključuje dodatne troškove. U tipičnom istraživanju dileme izbora ispitanici čitaju scenarij prema kojem su u razne opcije uložili različit iznos novca, truda ili vremena. Primjerice, u istraživanju Arkesa i Blumer (1985; eksperiment 5) scenarij je bio ovakav:

Zamislite da ste kupili kartu za dvodnevni izlet u Beč, što je stajalo 300 kuna. Nekoliko tjedana kasnije kupili ste kartu za dvodnevni izlet u Prag (600 kuna). Sigurni ste da bi Vam se izlet u Prag svidio, ali ste također sigurni da će Vam se izlet u Beč svidjeti više. Nekoliko dana nakon kupovine karata shvatili ste da je vrijeme putovanja u oba slučaja isto. Karte ne možete vratiti, pa morate odabrati: na koje ćete putovanje otići?

U ovom je scenariju u primamljiviju opciju uložen manji iznos, a u manje primamljivu veći. Prema teoriji racionalnog 
DRUŠ. ISTRAŽ. ZAGREB GOD. 22 (2013), BR. 2 STR. $347-366$

BOKULIĆ, M., BOVAN, K. EFEKT NEPOVRATNOGA... izbora, potpuno je jasno da treba odabrati primamljiviju opciju (tj. onu koja će donijeti veću ugodu u budućnosti). Međutim, $\mathrm{u}$ istraživanju je samo polovica ispitanika postupila tako (Arkes i Blumer, 1985). Drugim riječima, sudionici su uzimali u obzir nepovratne troškove i predstavili ovaj problem kao dvojbu: odlučiti se za primamljiviju opciju u koju smo uložili manje novca ili za manje primamljivu, ali skuplju, opciju. Scenariji su primijenjeni i u drugim istraživanjima kojima se pokazalo da su ljudi spremniji iskoristiti plaćene kupone za popust nego besplatne (Lala, 2005); spremniji iskoristiti plaćeno članstvo nego besplatno (Jang, Mattila i Bai, 2007); skloniji pohađati teniske lekcije unatoč teniskom laktu kako bi iskoristili uplaćeni iznos (Soman i Cheema, 2001); skloniji skijanju po nevremenu kako bi iskoristili skijašku kartu (Soman i Gourville, 2001).

Utjecaj nepovratnih troškova u dilemama izbora istraživao se i u realnim (nelaboratorijskim) uvjetima. U eksperimentu Arkesa i Blumer (1985; eksperiment 2) sudjelovale su osobe koje su na blagajnu kazališta došle kupiti pretplatničke karte. Neki su kupci dobili popust, a istraživači su pratili stupanj posjećenosti raznih skupina sudionika. Efekt nepovratnoga troška pokazao se u prvoj polovici sezone, kada su predstave najviše posjećivali sudionici koji su platili punu cijenu karte. U drugoj se polovici sezone nije pokazao efekt nepovratnoga troška, što su autori objasnili pretpostavkom da se efekt umanjuje s vremenom. Gourville i Soman (1998) potvrdili su ovu pretpostavku u nizu istraživanja, sugerirajući da se ljudi postupno adaptiraju na troškove iz prošlosti, pri čemu slabi njihov utjecaj na odluke. Primjerice, u jednom od istraživanja analizirali su podatke posjećenosti teretani u kojoj se članarina plaćala dvaput na godinu. Članovi su najčešće dolazili vježbati upravo onaj mjesec u kojem su platili članarinu, a posjećenost je zatim padala u idućih pet mjeseci, da bi opet narasla onaj mjesec kada se plaća članarina. Ovaj kontinuirani pad utjecaja nepovratnih troškova kroz vrijeme (kao i bilo kojega drugog dobitka ili gubitka) autori su nazvali deprecijacija plaćanja (ili smanjenje vrijednosti uložene svote; eng. payment depreciation).

\section{TEORETSKA OBJAŠNJENJA DILEME IZBORA}

\section{Mentalno računovodstvo}

Mentalno računovodstvo, koje je kao koncept uveo Richard Thaler (1980), odnosi se na način procjene, analiziranja i praćenja monetarnih troškova i dobiti. Drugim riječima, mentalnim računovodstvom opisujemo kako se ljudi ponašaju kao osobni računovođe. Pretpostavka je da kada nešto platimo, otva- 
DRUŠ. ISTRAŽ. ZAGREB GOD. 22 (2013), BR. 2, STR. 347-366

BOKULIĆ, M., BOVAN, K.: EFEKT NEPOVRATNOGA... ramo mentalni račun za taj objekt ili uslugu. Primjerice, kupnjom boce vina za 80 kuna otvaramo račun za vino na kojem je stanje -80 kuna. Kada iskoristimo objekt ili uslugu (popijemo vino), stanje na računu je 0 te ga možemo zatvoriti. U spomenutom primjeru biranja između dva putovanja ljudi se nalaze pred izborom između zatvaranja dvaju računa. Ako se odluče za privlačniju, ali jeftiniju, opciju (put u Beč za 300 kuna), zatvaraju račun koji je bio u manjem minusu, ali im ostaje otvoren račun s većim minusom (račun "put u Prag"=-600). S druge strane, ako se odluče za manje privlačnu, ali skuplju, opciju (put u Prag za 600 kuna), zatvaraju račun koji je bio u većem minusu. Ljudi imaju tendenciju održavanja i zatvaranja računa $u$ crnome, $t j$. na nuli ili $u$ pozitivnom stanju, a ne u crvenome, tj. u minusu, jer u protivnome osjećaju neugodu (Prelec i Loewenstein, 1998). Stoga je očekivano da ljudi žele zatvoriti račun koji je u većem minusu, kako bi osjećali što manju neugodu. Jednako tako, u primjeru višekratnih aktivnosti (npr. pohađanje teniskih lekcija) želimo do kraja iskoristiti kupljeno, kako bismo zatvorili račun bez minusa.

\section{Heuristika nerastrošnosti}

Drugo objašnjenje vezano je uz heuristiku nerastrošnosti (Arkes, 1996). Ona se odnosi na tendenciju ljudi da ne budu rastrošni, tj. da ne troše bez razloga, a očituje se u želji ljudi da plate samo nužnu cijenu proizvoda i da kupljeni proizvod iskoriste do kraja. Dilema izbora objašnjava se u okviru ove heuristike pretjeranom generalizacijom pravila o nerastrošnosti: imamo želju biti nerastrošni i u situacijama u kojima primjena te heuristike uvodi dodatne troškove. Primjerice, u Arkesovu istraživanju (1996) sudionici su bili skloniji otkazati dodatna ulaganja u projekt koji propada ako su iskorišteni materijal mogli prodati kao nešto korisno nego ako su ga mogli prodati u staro željezo. U oba scenarija isplata je bila jednaka, no na ispitanike je utjecala činjenica da prodaja materijala $u$ staro željezo podrazumijeva bačen trud. Glavni poticaj za uvođenje heuristike nerastrošnosti bio je taj što mentalno računovodstvo ne daje psihološku osnovu efekta nepovratnoga troška (Arkes i Blumer, 1985). Heuristiku nerastrošnosti stoga možemo konceptualizirati kao jedan od načina na koji ljudi doživljavaju račune $u$ crvenom: kao bačene, odnosno bezrazložno potrošene, resurse. No teško je možemo smatrati zamjenom za teoriju mentalnog računovodstva. Razlog je taj što mentalno računovodstvo objašnjava sve rezultate dobivene u okviru heuristike nerastrošnosti, ali i više. Primjerice, Soman i Gourville (2001) poslužili su se scenarijem u kojem su sudionici zamišljali četverodnevno skijanje te su morali izjaviti koliko bi bili spremni skijati se zadnji dan, uz pretpostavku da je 
DRUŠ. ISTRAŽ. ZAGREB GOD. 22 (2013), BR. 2 STR. $347-366$

BOKULIĆ, M., BOVAN, K. EFEKT NEPOVRATNOGA... taj dan oluja. Polovici sudionika rečeno je da su kupili četiri jednodnevne skijaške karte, a drugoj polovici da su kupili jednu četverodnevnu kartu za istu cijenu. Skupina koja je kupila jednodnevne karte bila je sklonija skijanju od skupine s četverodnevnom kartom. Za ovakvu situaciju jasno predviđanje daje samo teorija mentalnog računovodstva. Naime, u situaciji kada posjedujemo četverodnevnu kartu, cijena zadnjeg dana čini nam se manje bolnom, jer je bilježimo na zajednički račun s prva tri dana i na taj način imamo manji minus na računu. Ako imamo četiri jednodnevne karte, karta za zadnji dan čini zaseban račun na kojem je maksimalni minus (uopće nismo iskoristili kartu), koji ne možemo pribrojiti računima prethodnih dana. Navedeni rezultati idu u prilog mentalnom računovodstvu kao potpunijem teoretskom objašnjenju dileme izbora (također, vidi Soman i Cheema, 2001).

\section{ODLUKE O NASTAVKU ULAGANJA}

Sljedeća vrsta situacija u kojoj se proučavao utjecaj nepovratnih troškova jesu odluke o nastavku ulaganja. O takvoj situaciji govorimo kada je osoba prethodno započela neku aktivnost (primjerice, projekt) radi postizanja određenoga cilja (najčešće profita) te se suočava s izborom između nastavka i prekidanja te aktivnosti. Prema teoriji racionalnog izbora, jedino na što trebamo obraćati pozornost jesu vjerojatnosti za buduće dobiti, odnosno za postizanje ciljeva, dok nam podaci o prošlim troškovima mogu poslužiti samo kako bismo procijenili te vjerojatnosti. Međutim, kada je malo vjerojatno da ćemo dostići cilj, dotadašnji se ulozi čine potrošenima uzalud. Racionalna osoba te bi gubitke trebala prihvatiti i krenuti u aktivnost s povoljnijom budućnosti. Intuitivno se, međutim, čini kako nije lagano donijeti takvu odluku. Odlučimo li prestati s projektom, resursi su bespovratno potrošeni, no nastavimo li s njime, na dosadašnje troškove možemo nastaviti gledati kao na ulaganja koja će se u konačnici možda isplatiti. U takvim situacijama često imamo osjećaj da smo "previše uložili da bismo odustali".

U opisanim su situacijama ljudi skloni eskalaciji predanosti - donose niz odluka $u$ kojima su sve više i više posvećeni nastavku projekta. Riječ eskalacija podrazumijeva da je potpora projektu iracionalna, tj. da projekt ide prema gubitku. Na nepovratne troškove možemo gledati kao na dotadašnje gubitke koji se nastoje vratiti. No ovi su gubici samo jedan od niza faktora koji uzrokuju eskalaciju predanosti (potpunija lista uključuje karakteristike projekta, organizacijski kontekst i druge faktore; za pregled vidi Staw, 1997). Isto tako, nije svako ulaganje u projekt s gubicima neopravdano. Priroda je nekih projekata da dobici dolaze tek pri završetku projek- 
DRUŠ. ISTRAŽ. ZAGREB GOD. 22 (2013), BR. 2, STR. 347-366

BOKULIĆ, M., BOVAN, K. EFEKT NEPOVRATNOGA..

1 Naziv Concorde efekt rabi se za feno mene nepovratnih troškova kod životinja. Zanimliivo je spomenuti da, za razliku od liudi, ne postoje nepobitne demonstracije efekta nepovratnih troškova kod životinja (vidi Arkes i Ayton, 1999). ta, npr. kod razvoja novih proizvoda, što znači da nastavak ulaganja može biti racionalan i uz visoke nepovratne troškove (Northcraft i Wolf, 1984).

Prototip ovakvih odluka jest poslovni projekt u kojemu menadžer ili voditelj projekta odlučuje o tome je li buduća isplativost projekta dovoljno velika da opravda dodatna ulaganja. Istraživanja eskalacije predanosti velika su potencijalna dobit za poslovni svijet, jer sve više kompanija poslove obavlja projektima. Drugi naziv za efekt nepovratnoga troška, Concorde efekt, ${ }^{1}$ upravo dolazi od naziva jednog od poznatijih propalih projekata, razvoja nadzvučnog aviona Concorde (Arkes i Ayton, 1999). Osim poslovnih investicija, fenomen eskalacije predanosti često se prepoznaje u ratu, gdje se s grozotom "ulaganja" ljudskih života teško pomiriti ako nije postignut nikakav cilj (Staw, 1976). Spominjanje ratnih žrtava tako može ljude navesti na to da daju veću podršku ratu, no samo ako ih se navede na to da na žrtve gledaju kao na nepovratni trošak (vidi Schott, Scherer i Lambert, 2011 za eksperimentalnu demonstraciju tog efekta).

Važnost ovih istraživanja leži i u tome što kod odluka o nastavku ulaganja postoji velik potencijal za gubitke. Eskalacija predanosti neuspješnom projektu podrazumijeva da se gubici s vremenom povećavaju. Naime, svaka nova odluka o nastavku ulaganja stavlja nas na idućem koraku pred još veće nepovratne troškove, s potencijalno još snažnijim utjecajem. Za ilustraciju ovog umnažanja gubitaka možemo navesti primjer projekta izgradnje nuklearne elektrane Shoreham, koji je bio predmetom studije slučaja o eskalaciji predanosti (Ross i Staw, 1993). Početna procjena troškova za izgradnju elektrane bila je 70 milijuna dolara, no u 20 godina loših odluka cijena se popela na konačnih 5 milijardi, a da elektrana nikada nije proradila.

Visoki potencijal za gubitke i velika primjenjivost učinili su ovo područje istraživanja vrlo zanimljivim i istraživačima i praktičarima, ali i poprištem brojnih kontroverzi. Sama ideja da je eskalacija predanosti ozbiljan problem čini se iz ekonomističke perspektive problematičnom. Tržišni mehanizmi trebali bi iskorijeniti tvrtke koje eskaliraju u problematičnim projektima, jer takve tvrtke najčešće propadnu ili ih kupi netko drugi (Tang, 1988). Iako rizici od većih gubitaka sigurno vode do toga da su poslovne organizacije opreznije u donošenju odluka od ljudi u svakodnevnim situacijama, pretpostavka o efikasnom tržištu ne može biti jamac da se ekonomski loše odluke jednostavno ne donose, što pokazuje i nedavna gospodarska recesija (Schiller, 2005).

Istraživači na ovom području rabili su dvije vrste eksperimentalnih nacrta. Prva se uvelike oslanja na upitničke studije kakve su započeli Arkes i Blumer (1985). Ispitanicima se 
DRUŠ. ISTRAŽ. ZAGREB GOD. 22 (2013), BR. 2 STR. 347-366

BOKULIĆ, M., BOVAN, K. EFEKT NEPOVRATNOGA... izloži kratak scenarij, u kojem se od njih traži da se zamisle u ulozi menadžera koji donosi odluku o tome treba li nastaviti s nekim projektom. Ovisno o eksperimentalnoj situaciji, ispitanicima se izloži da je na projekt do sada potrošeno mnogo ili malo, tj. da su nepovratni troškovi visoki ili niski. Primjerice, $\mathrm{u}$ čestom scenariju o avionu nevidljivom za radar (Arkes i Blumer, 1985; eksperiment 3) ispitanike se pita bi li nastavili ulagati u razvoj aviona, uz pretpostavku da je konkurencija nedavno izbacila na tržište mnogo bolji model. Uz veće nepovratne troškove, ispitanici su češće odgovarali da bi nastavili s ulaganjem (vidi i studiju Garlanda, 1990, koji replicira isti efekt uz pet razina nepovratnih troškova). Međutim, metodologija Arkesa i Blumer (1985) doživjela je kritiku zbog toga što se u njihovim scenarijima zapravo rabe dvije teoretske važne varijable: nepovratni troškovi i stupanj dovršenosti projekta (Conlon i Garland, 1993). Naime, što je u projekt više uloženo, to je on vjerojatno i bliže svojem završetku. Ispitanici su stoga možda snažnije osjećali da je korisnije "završiti što su započeli" nego što su bili pod utjecajem nepovratnih troškova. No Moon je (2001a) demonstrirao da su oba faktora utjecajna.

Drugi tip eksperimentalnih nacrta jest simulacija donošenja poslovnih odluka koju uvodi Staw (1976). U njegovu su eksperimentu sudionici pristupili zadatku za koji im je rečeno da testira njihovu uspješnost $u$ donošenju poslovnih odluka. Trebali su se postaviti u ulogu direktora jedne tvrtke i odlučiti između ulaganja $u$ jedan od dva odjela za razvoj proizvoda za koje su dobili relevantne financijske podatke. Nakon odluke dobili su podatke o uspješnosti odjela za 5 godina. Polovica sudionika bila je obaviještena o uspjehu, a druga polovica o neuspjehu odabranog odjela. Potom su trebali odlučiti o nastavku ulaganja u ista dva odjela, no ovaj put su sami mogli rasporediti proračun. Predanost prvotno odabranom projektu očitovala se u količini novca koji su mu namijenili u ovoj odluci o budžetiranju. Rezultati su pokazali da su sudionici u prvotno odabrani odjel ulagali više novca kada je odjel bio neuspješan, što pokazuje kako su bili nespremni pomiriti se s uzaludno potrošenim resursima na prvom koraku.

\section{TEORETSKA OBJAŠNJENJA ESKALACIJE PREDANOSTI}

\section{Teorija izgleda}

Zamišljena kao teorija koja predviđa odluke ljudi u nesigurnim (probabilističkim) uvjetima, teorija izgleda (eng. prospect theory; Kahneman i Tversky, 1984) pretpostavlja da primamljivost neke aktivnosti ovisi o ishodima koje od nje očekujemo i pripadajućim vjerojatnostima, ali veliku važnost pridaje i formatu (okviru) kojim su te informacije predstavljene. Primjerice, od- 
DRUŠ. ISTRAŽ. ZAGREB GOD. 22 (2013), BR. 2, STR. $347-366$

BOKULIĆ, M., BOVAN, K.: EFEKT NEPOVRATNOGA.. luka će ovisiti o tome jesu li inače identični ishodi prikazani kao gubici ili smanjeni dobici, jer smo na gubitke osjetljiviji. Zbog toga bismo trebali biti manje uzrujani ako projekt donosi manju dobit nego ako ulazi u veće troškove (Northcraft i Wolf, 1984). Dvije generalizacije važne su za efekt nepovratnoga troška. Prva jest sklonost riziku kada su ishodi prikazani kao gubici (nazvana "traženje rizika"). U terminima teorije izgleda, nepovratni troškovi postavljaju osobu koja donosi odluku u domenu gubitaka, tj. navode je da promišlja je li bolje prihvatiti siguran gubitak (odustati od projekta) ili riskirati još veći. Prema teoriji izgleda, $\mathrm{u}$ takvim smo situacijama skloniji riskirati. Jedan od bitnih preduvjeta za ovakvu generalizaciju jest da ljudi dobitke i gubitke promatraju za kategoriju koja je najsmislenija s obzirom na kontekst (Thaler, 2004). U ovom slučaju riječ je o budžetu cjelokupnoga projekta, pa se sve odluke oko njega promatraju kao povezane. Zbog toga se gubici na nekom projektu žele vratiti zaradom upravo na tom projektu, umjesto da se usmjere na druge (možda povoljnije) mogućnosti.

Druga je generalizacija da su ljudi skloni precjenjivati važnost sigurnih ishoda ("efekt sigurnosti"). Ishodi s vrlo visokim i vrlo niskim vjerojatnostima, odnosno oni koji se gotovo sigurno ili hoće ili neće ostvariti, nose mnogo veću težinu u donošenju odluka nego ishodi koji imaju umjerenu vjerojatnost da se ostvare. Drugim riječima: promjene blizu krajnjih vjerojatnosti mnogo jače utječu na konačnu odluku nego promjene oko srednjih vjerojatnosti (npr. ako se šansa da ćemo izgubiti novac poveća sa $95 \%$ na $99 \%$, to će mnogo jače utjecati na našu odluku nego ako je riječ o povećanju sa $50 \%$ na $54 \%$ ). U kontekstu nepovratnih troškova ovaj efekt vodi k ovom zaključku: kako odustajanje od projekta podrazumijeva siguran gubitak, riječ je o odbojnijoj opciji nego što je vjerojatan (ali ne i potpuno siguran) veći gubitak koji nas očekuje ako nastavimo s ulaganjem.

\section{Samoopravdavanje}

Najprikladnije objašnjenje eskalacije predanosti trenutačno se čini ono koje izlaže Staw (1976; vidi i Brockner, 1992; Staw, 1997), u kojem se taj fenomen objašnjava općenitijom teorijom kognitivne disonance. Prema teoriji kognitivne disonance (Festinger, 1957), osoba koja ima nesukladne kognicije (npr. stavove) ili kognicije nesukladne s ponašanjem osjeća nelagodu koju nastoji ukloniti njihovim usklađivanjem. Ova je nelagoda posebno izražena kada je u pitanje dovedeno samopoštovanje pojedinca, jer gotovo svi ljudi žele o sebi imati pozitivno mišljenje i osjećati se kompetentno i moralno (Aronson, 1992). Razmatrajući nastavljanje ulaganja u neuspješan projekt koji 
DRUŠ. ISTRAŽ. ZAGREB GOD. 22 (2013), BR. 2, STR. $347-366$

BOKULIĆ, M., BOVAN, K. EFEKT NEPOVRATNOGA... je sama prethodno zagovarala, osoba može prihvatiti neuspjeh ili nastojati ostvariti uspjeh novim ulaganjem. Odustajanje od projekta dovodi u pitanje razboritost njegova započinjanja, a time i status pojedinca kao mudra donositelja odluka. Zato se predviđa da su ljudi skloni nastaviti s ulaganjem kako bi opravdali svoju prvotnu odluku (Staw, 1976). Ovime demonstriraju "retrospektivnu racionalnost" (zapravo racionalizaciju), gdje je buduće ponašanje usmjereno prema demonstriranju prošle odluke kao racionalne, umjesto da se racionalna odluka donese $u$ sadašnjim uvjetima imajući na umu buduće dobiti i troškove (Staw, 1981). Nepovratni troškovi imaju ulogu utoliko što je teže prihvatiti neuspjeh koji je nas ili tvrtku stajao više novca, no možda je važniji "psihološki ulog": stupanj na kojemu smo vjerovali u uspjeh projekta ili stupanj na kojem smo projekt smatrali "svojim".

Staw (1976) pretpostavlja da su za poticanje opravdavanja prethodne odluke potrebna dva uvjeta - prethodno započeti projekt treba imati negativne ishode te se osoba treba osjećati osobno odgovorna za njegovu inicijaciju. U prethodno opisanom eksperimentu naveli smo kako su sudionici ulagali više novca u odjel koji je bio neuspješan nego u uspješan. Prema teoriji disonance, to se događa zato što su ljudi skloni opravdavati prethodno donesene odluke, a potreba za opravdavanjem postoji samo ako se ta odluka retrospektivno čini lošom. Staw je (1976) $\mathrm{u}$ istom eksperimentu manipulirao is faktorom odgovornosti. Neki su sudionici u prvom koraku sami birali odjel u koji žele uložiti novac (situacija opisana ranije), dok je drugima bilo rečeno da je prvotnu odluku donio njihov prethodnik. U skladu s teorijom disonance, sudionici su bili skloni ulagati veći iznos u prvotno odabrani odjel samo kad su bili osobno odgovorni za odluku. S druge strane, oni koji nisu sami donijeli odluku nisu imali niti što opravdavati. U idućem tekstu navodimo rezultate koji dodatno potvrđuju objašnjenje eskalacije samoopravdavanjem. Ako nije drugačije navedeno, istraživanja su se koristila Stawovim (1976) scenarijem.

Percepcija osobne odgovornosti osobe koja donosi odluku temeljni je pokretački faktor samoopravdavanja. Ako odgovornost možemo nekako negirati, ti. odvojiti osobu od razloga neuspjeha, onda bi i predanost projektu trebala biti manja. Tako su Leatherwood i Conlon (1987) pokazali da ispitanici manje ulažu u nastavak projekta ako im se kaže da je za neuspjeh projekta kriv štrajk na koji su pozivali sindikati. Whyte je (1991) istraživao podjelu odgovornosti u kontekstu odlučivanja u grupi, koristeći se upitničkim manipulacijama sličnima Arkesu i Blumer (1985). Ako smo odluku o stupanju u projekt donijeli grupno, za naknadni neuspjeh odgovorni su svi članovi grupe, a pojedinačna se odgovornost smanjuje. Impli- 
DRUŠ. ISTRAŽ. ZAGREB GOD. 22 (2013), BR. 2, STR. $347-366$

BOKULIĆ, M., BOVAN, K.: EFEKT NEPOVRATNOGA... kacija ovog istraživanja jest $\mathrm{u}$ tome što su projekti pokrenuti od grupe manje osjetljivi na eskalaciju predanosti, a u poslovnom je svijetu ovo češća situacija u odnosu na samostalno započete projekte (Whyte, 1991). Sivanathan, Molden, Galinsky i Ku (2008) proučavaju može li se disonanca nakon loše odluke smanjiti indirektno: ako se ispitanicima pruži prilika da potvrde svoju vrijednost $u$ nekoj drugoj sferi umjesto $u$ donošenju odluka. Ovo bi trebalo umanjiti eskalaciju, jer nestaje potreba da se vrati osjećaj vlastite vrijednosti. Ispitanici koji su prije donošenja odluke o nastavku ulaganja mogli potvrditi svoju privrženost nekoj njima važnoj vrijednosti (npr. religijskim vrijednostima) manje su ulagali u prvotno odabrani projekt. S druge strane, ako ispitanike pohvalimo kao dobre donositelje odluka, onda njihovu pozornost usmjeravamo upravo na onu sposobnost koja je dovedena u pitanje. Ispitanici kojima je rečeno da su prema rezultatima testa ispali među najboljima u donošenju odluka eskaliraju još više nego oni bez te informacije. U slučaju nečijeg neuspjeha intuitivno smo možda skloni ohrabriti osobu podsjetivši je da je inače upravo u toj aktivnosti uspješna. Ovo istraživanje pokazuje da takvo povlađivanje može pojačati već prisutnu sklonost opravdavanju prethodnog neuspjeha.

Zaključno, iako neki autori smatraju da teorija izgleda može objasniti sve rezultate na temu eskalacije predanosti (Whyte, 1986), rezultati navedeni u korist objašnjenju putem samoopravdavanja sugeriraju da tome nije tako (vidi i Brockner, 1992). Ipak, na samoopravdavanje i teoriju izgleda ne treba gledati kao na međusobno isključiva teoretska objašnjenja (Brockner, 1992; Staw, 1997). Kao čisto kognitivni fenomen, teorija izgleda čini se primjenjivija na situacije u kojima ljudima nije ugrožen identitet, odnosno u situacijama u kojima ljudi nisu motivirani da svoje odluke donose u nekom specifičnom smjeru. Ljudi, naime, mogu biti osjetljivi na nepovratne troškove i kada nisu odgovorni za početnu odluku (Arkes i Blumer, 1985). Ovaj je efekt posebno uočljiv u izjavama političara koji kod javnosti žele potaknuti stav da se neki preskupi projekt treba nastaviti do kraja samo zbog toga što je na njega već potrošeno mnogo novca. Iako javnost nije osobno odgovorna za odluku, predstavljanje projekta u domeni gubitaka ("već smo toliko potrošili ...") čini je sklonijom da prihvati prijedloge o nastavljanju ulaganja.

\section{Upravljanje dojmovima i organizacijska kultura}

Objašnjenje samoopravdanjem pretpostavlja da se odluke donose $\mathrm{u}$ socijalnom vakuumu, no stvarne odluke donose se $\mathrm{u}$ socijalnom okruženju u kojem smo izloženi evaluacijama drugih. Odluke ćemo stoga, možda i češće opravdavati drugima 
DRUŠ. ISTRAŽ. ZAGREB GOD. 22 (2013), BR. 2, STR. $347-366$

BOKULIĆ, M., BOVAN, K. EFEKT NEPOVRATNOGA... nego sebi, procesom koji zovemo upravljanje dojmovima. Upravljanje dojmovima jest svjesno ili nesvjesno samoprezentiranje s namjerom stvaranja određenoga dojma kod drugih osoba koji je u skladu s našim ciljevima (Aronson, Wilson i Akert, 2005). Zaposlenici u tvrtkama žele da ih percipiramo kao sposobne i uspješne, jer su te karakteristike povezane s napredovanjem, plaćom i socijalnim statusom u poduzeću (Staw, 1981).

U poslovnom je svijetu izrazito važna sposobnost donošenja dobrih odluka. Međutim, često se sposobnost osobe ne procjenjuje na temelju kvalitete donesenih odluka nego na temelju njihovih posljedica, što je tendencija koju zovemo "pristranost prema ishodu" (eng. outcome bias) (Baron, 2008). Tako ćemo sposobnost voditelja projekta vrednovati više na temelju ishoda projekta negoli na njegovu procesu odlučivanja. Stoga će voditelji neuspjeloga projekta imati potrebu i drugima, a ne samo sebi, opravdavati svoje ulaganje u neuspješan projekt (Fox i Staw, 1979; Staw, 1981).

Fox i Staw (1979) demonstriraju utjecaje opravdavanja drugima u istraživanjima koja pokazuju kako su ispitanici skloniji eskalaciji kad je njihov posao opisan kao nesiguran (da im pozicija ovisi o uspjehu trenutačnoga projekta) i kada im je rečeno da nadređeni ne podupiru projekt. Ističu da u takvim situacijama nepovratni troškovi psihološki utječu indirektno na osobu koja donosi odluke, i to načinom na koji ona zamišlja reakcije drugih na potrošeni novac. Osoba očekuje da će nadređeni biti pod utjecajem pristranosti prema ishodima: što je više novca potrošila na neuspješan projekt, smatrat će je sve slabijim voditeljem. Slično Brockner, Rubin i Lang (1981) pokazuju da su sudionici skloniji eskalaciji u situaciji kada odluku donose pred publikom, $\mathrm{u}$ odnosu na situaciju kada su to činili nasamo.

Unatoč sličnim predikcijama, samoopravdavanje i upravljanje impresijama različito pristupaju analizi racionalnosti. Naime, sklonost održavanju pozitivne slike pred drugima racionalna je jer može značiti razliku između dobivanja promaknuća i otkaza (Kanodia, Bushman i Dickhaut, 1989; vidi i Staw, 1981). Voditelj projekta najčešće je menadžer čije su aktivnosti usmjerene prema čuvanju vlastita ugleda. Ugled menadžera povezan je s njegovom plaćom i cijenom na tržištu rada, a povećava se s uspjehom projekata koje vodi. Ako menadžer odustane od projekta, njegov se ugled smanjuje, čime mu pada i cijena na tržištu rada, dok nastavak ulaganja u projekt u najmanjoj mjeri održava jednaku razinu ugleda.

Iracionalnom bismo onda mogli prozvati okolinu koja stavlja premiju na takvo ponašanje. Staw je (1981) pokazao da učestalost eskalacije predanosti u nekom poduzeću ovisi o organizacijskoj kulturi i normama, odnosno o ponašanju koje 
DRUŠ. ISTRAŽ. ZAGREB GOD. 22 (2013), BR. 2, STR. 347-366

BOKULIĆ, M., BOVAN, K. EFEKT NEPOVRATNOGA.. se smatra prihvatljivim unutar tvrtke. Eskalacija će se birati kao način za opravdavanje svoje odluke pred drugima ako se u kompaniji cijeni ustrajnost zaposlenika (vlada norma konzistentnosti) i ako je kultura organizacije takva da se priznavanje pogreške izrazito osuđuje (Staw i Ross, 1987; prema Brockner, 1992). Ona će biti rjeđa ako se u kompaniji cijeni eksperimentiranje te se zaposlenike potiče da priznaju svoje pogreške. Međutim, Staw (1981) ističe kako imamo tendenciju najviše cijeniti upravo osobe koje su ustrajale u nečemu, čak i kada je stanje bilo loše, a na kraju su ipak uspjele. Tu tendenciju naziva "efekt heroja". Budući da je ovaj fenomen prisutan na razini cjelokupnoga društva, vjerojatno će se i u poduzećima tražiti "heroji" i na taj način poticati eskalacija predanosti.

\section{SMANJIVANJE PRISTRANOSTI - IMPLIKACIJE ZA RUKOVODITELJSKU PRAKSU}

Istraživanja pristranosti u odlučivanju bitna su za poslovnu praksu onda kad pokazuju kako te pristranosti najbolje izbjeći. Simonson i Staw (1992) dijele strategije za smanjivanje pristranosti na one koje smanjuju utjecaje iracionalnih mehanizama i one koje povećavaju sklonost racionalnom rezoniranju.

Prvoj skupini pripadaju strategije za smanjivanje potrebe za opravdanjem odluke ili uklanjanje njezina javljanja. Najjednostavniji način jest zamijeniti osobu odgovornu za projekt, tako da osoba koja odlučuje o početnom ulaganju nije ista kao i osoba koja odlučuje o nastavku ulaganja. Od novog voditelja onda možemo očekivati objektivnije procjene isplativosti ulaganja. Testirajući tu hipotezu, Staw, Barsade i Koput (1997) pokazali su da se problematični bankarski zajmovi brže rješavaju ako je došlo do promjene menadžera koji te zajmove ugovaraju. Preporuka tvrtkama, međutim, ne mora biti da moraju posegnuti za tako drastičnim postupkom kao što je smjenjivanje zaposlenika. Alternativa jest podijeliti radne zadatke tako da jedna osoba (ili grupa ljudi) donosi odluku o započinjanju projekta, dok su drugi zaduženi za donošenje procjena o uspješnosti i nastavku ulaganja. Drugi se savjeti usmjeravaju ne na eliminaciju nego na umanjivanje potrebe za opravdavanjem. Simonson i Staw su (1992) jednoj skupini ispitanika u nacrtu nalik Stawovu (1976) napomenuli da zadatak odlučivanja ne govori ništa o njihovim poslovnim sposobnostima. Ovi ispitanici znatno su manje eskalirali od ispitanika u prvotnom istraživanju. Slično tome, ako se zaposlenicima naglasi da se njihov rad cijeni neovisno o uspjehu projekata te da njihov posao ili promaknuće neće doći u opasnost, neće se osjećati toliko ugroženi ako im se projekti pokažu neuspješnima. Ako zaposlenicima ne želimo umanjivati odgovornost, možemo potkrijepiti njihovo samopoštovanje aktivnostima 
DRUŠ. ISTRAŽ. ZAGREB GOD. 22 (2013), BR. 2,

BOKULIĆ, M., BOVAN, K. EFEKT NEPOVRATNOGA... STR. $347-366$

nevezanima uz projekt. Umjesto da se dokazuju kroz neuspješan projekt i stvore još veće troškove, rotacijom poslova nakon pristiglih negativnih povratnih informacija možemo odgovornim menadžerima pružiti priliku da se dokažu na nekom drugom zadatku (Sivanathan i sur., 2008). Na taj se način osjećaju bolje u vezi sa svojim sposobnostima i smanjuje im se potreba da opravdavaju neuspjeh projekta.

Drugom skupinom strategija nastojat ćemo kod zaposlenika potaknuti racionalno donošenje odluka. Simonson i Staw su (1992) demonstrirali da samo poticanje na pažljivo vaganje razloga za i protiv nastavka ulaganja, bez jasnih napomena kako to učiniti, ne čini veliku razliku. S druge strane, ako su ispitanici jače motivirani da donose dobre odluke, npr. ako im je rečeno da će se procjenjivati proces kojim su do njih došli, eskalacija se smanjuje. Ovo je važan rezultat jer pokazuje kako se motivi za opravdavanje mogu korisno usmjeriti ako je ono što se opravdava racionalnost metode kojom smo došli do odluke. Racionalnost možemo potaknuti i tako da ispitanike usmjerimo prema konkretnim strategijama donošenja odluka. Od posebnog je značenja jasno postavljanje očekivanja od projekta i ograničavanje buduće potrošnje (Brockner, Shaw i Rubin, 1979; Simonson i Staw, 1992). Ako unaprijed definiramo kakav ishod znači neuspjeh, kasnije ćemo biti manje slobodni u interpretacijama dvosmislenih informacija. Osim toga, odgovornima za projekt time se implicitno sugerira da je odustajanje prihvatljiva strategija u slučaju neuspjeha te ih se navodi da razmišljaju o alternativnim strategijama ako se neuspjeh dogodi.

\section{METODOLOŠKE I EKONOMISTIČKE KRITIKE}

Istraživanja odluka o nastavku ulaganja mahom su laboratorijska, što podrazumijeva niži realizam i manju kompleksnost eksperimentalnih situacija u odnosu na svakodnevicu. Još problematičnije, varijable od interesa ponekad su operacionalizirane tako da se ispitanike samo navodi da zamisle određene situacije. Primjerice, Arkes i Blumer su (1985) operacionalizirali osobnu odgovornost tako što su svojim ispitanicima jednostavno napisali da su odluku donijeli oni ili pak netko drugi. Ovakva niska ekološka valjanost baca sumnje na mogućnost generalizacije rezultata na realni poslovni svijet, posebno s obzirom na kritike prema kojima su tvrtke u kompetitivnom okruženju pod mnogo većim pritiskom da zauzdaju iracionalno donošenje odluka (Tang, 1988). Također, za razliku od stvarnih uvjeta, u uvjetima laboratorija ispitanici nemaju što izgubiti (Zardkoohi, 2004). No artificijelnost laboratorijskih uvjeta iz istih je razloga nepovoljna i za istraživače samoopravdavanja jer se disonanca javlja jače za odluke s ozbiljnijim 
DRUŠ. ISTRAŽ. ZAGREB GOD. 22 (2013), BR. 2, STR. $347-366$

BOKULIĆ, M., BOVAN, K. EFEKT NEPOVRATNOGA... posljedicama (Aronson i sur., 2005). U laboratoriju zbog manjka ozbiljnih posljedica i niskog realizma ispitanici se osjećaju manje uključenima, a u takvim situacijama teže je pokazati utjecaj samoopravdanja ili upravljanja impresijama (Brockner, 1992). Stoga je opravdano zaključiti da su ovi psihološki utjecaji vjerojatno još i jači u realnim okolnostima. No iako laboratorijski eksperimenti dopuštaju jasnije zaključivanje zbog toga što omogućuju izolaciju i kontrolu relevantnih faktora, njihov niski realizam jest problematičan i za istraživanje psiholoških faktora i za povezivanje s poslovnim svijetom. Zbog toga je potrebno više terenskih istraživanja (Staw i sur., 1997; Ross i Staw, 1993), kao što je kvalitativno istraživanje EXPO 86 svjetskoga sajma (Ross i Staw, 1986). Autori su proučavali novinske izvještaje, izjave za medije, interne izvještaje i intervjue vezane uz sajam. Sajam se pokazao potpunim financijskim promašajem, no proučavanje ovih podataka pokazalo je kako je s povećanjem troškova rastao i optimizam oko očekivanoga broja posjetitelja. Autori su pronašli dokaze o utjecaju psiholoških faktora kao što su osobna odgovornost, opravdavanje pred drugima (projekt su financirali porezni obveznici), te političkih pritisaka da se ostane predan početnoj zamisli. Međutim, valja spomenuti kritiku Zardkoohija (2004), koji smatra da se ovaj primjer (kao ni primjer nuklearne elektrane Shoreham, Ross i Staw, 1993), ne može generalizirati na većinu tvrtki. Razlog tomu jest što su u oba slučaja krajnju cijenu platile osobe koje nisu sudjelovale u odluci - porezni obveznici. Što je veći postotak troškova projekta koji se mogu prenijeti izvan organizacije, smatra Zardkoohi, to je vjerojatnije da će se eskalirati u projektu.

Skupina autora (Bowen, 1987; Northcraft i Wolf, 1984) dovodi u pitanje temeljnu tezu s kojom smo počeli, a to je da istraživanja eskalacije pokazuju kako ispitanici donose odluke koje odudaraju od racionalnog modela. Naime, prema njima, negativne povratne informacije, za kakve se smatralo da stvaraju potrebu za opravdanjem (Staw, 1976), nisu bile dovoljne da se projekt jasno odbaci kao neuspješan. Northcraft i Wolf (1984) smatraju da psihološke utjecaje ima smisla razmatrati samo kad su njihove predikcije jasno u suprotnosti s predikcijama racionalnih modela, a za to je potrebno da povratne informacije budu nedvosmisleno negativne ( $u$ tom slučaju bilo bi racionalno prekinuti s projektom). Štoviše, Bowen (1987) misli da je uz takve nepotpune povratne informacije racionalno nastaviti s ulaganjem. Bez povratnih informacija koje jasno upućuju na buduće dobitke i gubitke, Bowen smatra da će ljudi nastaviti s ulaganjem kako bi prikupili dodatne podatke ili dali dodatnu šansu projektu. Osim što je Bowenov model presiromašan da objasni sve rezultate na tom području, dodatni je empirijski problem što ispitanici negativne povratne 
DRUŠ. ISTRAŽ. ZAGREB GOD. 22 (2013), BR. 2 STR. $347-366$

BOKULIĆ, M., BOVAN, K. EFEKT NEPOVRATNOGA... informacije doista i doživljavaju kao negativne (npr., Conlon i Parks, 1987), a kad ih se pita za razloge ponovnog ulaganja, ne navode da su očekivali pozitivne rezultate (Brockner, 1992). Nadalje, u istraživanjima u kojima su podaci bili nedvosmisleni i dalje se dobivaju utjecaji faktora kao što su podjela odgovornosti (Leatherwood i Conlon, 1987). Stoga ne možemo reći da uz odgovarajuće informacije ekonomski motivi otklanjaju psihološke utjecaje.

No još je važniji prigovor ovaj: nedvosmislene su povratne informacije o budućim dobitima u realističnim uvjetima iznimka, a ne pravilo (Simonson i Staw, 1992). Budući da dobici i gubici ovise o brojnim faktorima unutar vlastite organizacije i tuđih organizacija te stanja na tržištu, procjene na koje se možemo osloniti jesu rijetkost (za popularni prikaz neizvjesnosti procjena na tržištu vidi Taleb, 2007). Važno je iznijeti zaključak da utjecaj psiholoških faktora ne sugerira umanjen utjecaj ekonomskih faktora (Staw i sur., 1997), nego oba seta faktora utječu na odlučivanje. Ovisno o organizacijskom kontekstu, jedni ili drugi mogu biti istaknutiji, a relevantan je faktor i priroda samoga projekta, npr. odnos između nepovratnih troškova te vjerojatnosti budućeg uspjeha. Ako su nepovratni troškovi ( $\mathrm{tj}$. akumulacija gubitaka) nedvosmislen pokazatelj da je projekt osuđen na propast, osobe koje donose odluke neće nastavljati ulaganje. Kad se tipičan scenarij s nepovratnim troškovima prebaci u kontekst naftnih bušotina, profesionalni geolozi pokazuju deeskalaciju, tj. rjeđe nastavljaju ulaganje ako je u scenariju navedeno da je napravljeno više bušotina te potrošeno više novca (Garland, Sandefur i Rogers, 1990). Razlog tomu jest što su profesionalni geolozi (za razliku od studenata: vidi Garland i sur., 1990; eksperiment 2) upoznati s činjenicom da ako se uz početne bušotine ne pronađe nafta, malo je vjerojatno da će se naći i nakon dodatnih bušenja.

\section{INTERINDIVIDUALNE RAZLIKE}

\begin{tabular}{l}
\hline Kad govorimo o utjecaju interindividualnih razlika na do- \\
nošenje odluka, intuitivno bi prva pretpostavka bila da inteli- \\
gentniji ljudi donose bolje odluke, a to je pokazano i kod efek- \\
ta nepovratnih troškova. Stanovich i West (1998) svoje su ispi- \\
tanike pitali koliko bi puta otišli igrati tenis s ozlijeđenim lak- \\
tom - kada su platili članstvo u teniskom klubu ili kada ga ni- \\
su platili. Ispitanici s višim rezultatima na SAT-u (američkom \\
testu akademske sposobnosti, koji visoko korelira s općom in- \\
teligencijom) češće su davali isti odgovor u oba slučaja, po- \\
kazujući da su smatrali kako nepovratne troškove treba zane- \\
mariti. Stanovich i West (1998) smatraju da rezultati poput o- \\
vih, koji pokazuju da inteligentniji ljudi češće odgovaraju u \\
skladu s teorijom racionalnog izbora, sugeriraju da je taj mo-
\end{tabular}


DRUŠ. ISTRAŽ. ZAGREB GOD. 22 (2013), BR. 2, STR. $347-366$

BOKULIĆ, M., BOVAN, K. EFEKT NEPOVRATNOGA...

\section{ZAKLJUČAK}

\section{LITERATURA}

del uistinu normativan (vidi Stanovich i West, 2000 za opsežniju raspravu). Utjecaj nepovratnih troškova, osim o inteligenciji, ovisi i o crtama ličnosti. Primjerice, Moon se (2001b) koristio scenarijem aviona nevidljivog za radar i pokazao kako su osobe koje imaju izraženiji osjećaj za izvršavanje dužnosti, što je jedan od aspekata savjesnosti, manje sklone eskaliranju predanosti. S druge strane, osobe koje imaju visoku potrebu za uspjehom podložnije su efektu nepovratnih troškova. Schaubroeck i Williams (1993) pokazali su kako su osobe s ličnosti tipa A sklonije eskaliranju predanosti. Takvu ličnost karakterizira visoka kompetitivnost, neprijateljstvo, uključenost u posao i želja za kontrolom (Wiebe i Smith, 1997). Autori pretpostavljaju da su ove osobe sklonije za negativne ishode kriviti sebe, zbog čega imaju jaču potrebu za samoopravdavanjem.

Iako teorija racionalnog donošenja odluka pretpostavlja kako nepovratni troškovi ne bi trebali utjecati na naše odluke, niz istraživanja koje smo opisali pokazuju da taj utjecaj postoji. No moramo ponoviti opću kritiku većine navedenih istraživanja, a to je da su često provođena samo u obliku upitnika. Ovakva metodologija zasigurno ne aktivira sve psihološke procese kakvi se aktiviraju u relevantnim okruženjima, što dovodi u pitanje mogućnost generalizacije rezultata.

Također, jasno je kako ne postoji jedinstveni teoretski okvir u kojem bi se svi ovi nalazi mogli opisati. Jedan od mogućih razloga jest razjedinjenost bihevioralno-ekonomske i socijalno-kognitivne literature, a time i manjak radova koji sintetiziraju nalaze iz ovih dvaju smjerova istraživanja. Buduće napretke $\mathrm{u}$ razumijevanju ovoga fenomena vidimo $\mathrm{u}$ rasvjetljavanju temeljnih percepcija: kako ljudi konceptualiziraju svoje troškove i projekte, odnosno, specifičnije, u kojim točno uvjetima dolazi do "bilježenja" nepovratnih troškova, a u kojim se uvjetima ti troškovi zanemaruju. Jer jedno je sigurno usprkos savjetima ekonomista, njihov je utjecaj teško izbjeći.

Arkes, H. R. (1996). The psychology of waste. Journal of Behavioral Decision Making, 9(3), 213-224. doi:10.1002/(SICI)1099-0771(199609)9: 3<213::AID-BDM230>3.0.CO;2-1

Arkes, H. R. i Ayton, P. (1999). The sunk cost and Concorde effects: Are humans less rational than lower animals? Psychological Bulletin, 125(5), 591-600. doi:10.1037//0033-2909.125.5.591

Arkes, H. R. i Blumer, C. (1985). The psychology of sunk cost. Organizational Behavior and Human Decision Processes, 35(1), 124-140. doi:10. 1016/0749-5978(85)90049-4

Arnold, R. A. (2008). Economics. Mason: South-Western Cengage Learning. 
DRUŠ. ISTRAŽ. ZAGREB GOD. 22 (2013), BR. 2, STR. 347-366

BOKULIĆ, M., BOVAN, K. EFEKT NEPOVRATNOGA...
Aronson, E. (1992). The return of the repressed: Dissonance theory makes a comeback. Psychological Inquiry, 3(4), 303-311. doi:10.1207/s15327965p li0304_1

Aronson, E., Wilson, T. D. i Akert, R. (2005). Socijalna psihologija. Zagreb: Mate.

Baron, J. (2008). Thinking and deciding. Cambridge: Cambridge University Press.

Bowen, M. G. (1987). The escalation phenomenon reconsidered: Decision dilemmas or decision errors? Academy of Management Review, 12(1), 52-66. doi:10.2307/257993

Brockner, J. (1992). The escalation of commitment to a failing course of action: Toward theoretical progress. Academy of Management Review, 17(1), 39-61. doi:10.2307/258647

Brockner, J., Rubin, J. Z. i Lang, E. (1981). Face-saving and entrapment. Journal of Experimental Social Psychology, 17(1), 68-79. doi:10. 1016/0022-1031(81)90007-X

Brockner, J., Shaw, M. C. i Rubin, J. Z. (1979). Factors affecting withdrawal from an escalating conflict: Quitting before it's too late. Journal of Experimental Social Psychology, 15(5), 492-503. doi:10.1016/00221031(79)90011-8

Conlon, D. E. i Garland, H. (1993). The role of project completion information in resource allocation decisions. Academy of Management Journal, 36(2), 402-413. doi:10.2307/256529

Conlon, E. J. i Parks, J. M. L. (1987). Information requests in the context of escalation. Journal of Applied Psychology, 72(3), 344-350. doi:10. 1037/0021-9010.72.3.344

Festinger, L. (1957). A theory of cognitive dissonance. Stanford: Stanford University Press.

Fox, F. V. i Staw, B. M. (1979). The trapped administrator: Effects of job insecurity and policy resistance upon commitment to a course of action. Administrative Science Quarterly, 24(3), 449-471. doi:10.2307/ 2989922

Garland, H. (1990). Throwing good money after bad: The effect of sunk costs on the decision to escalate commitment to an ongoing project. Journal of Applied Psychology, 75(6), 728-731. doi:10.1037/0021-9010.75. 6.728

Garland, H., Sandefur, C. A. i Rogers, A. C. (1990). De-escalation of commitment in oil exploration: When sunk costs and negative feedback coincide. Journal of Applied Psychology, 75(6), 721-727. doi:10. 1037/0021-9010.75.6.721

Gourville, J. T. i Soman, D. (1998). Payment depreciation: The behavioral effects of temporally separating payments from consumption. Journal of Consumer Research, 25(2), 160-174. doi:10.1086/209533

Jang, D., Mattila, A. S. i Bai, B. (2007). Restaurant membership fee and customer choice: The effects of sunk cost and feelings of regret. International Journal of Hospitality Management, 26(3), 687-697. doi:10. 1016/j.ijhm.2006.06.001

Kahneman, D. i Tversky, A. (1984). Choices, values, and frames. American Psychologist, 39(4), 341-350. doi:10.1037/0003-066X.39.4.341 
DRUŠ. ISTRAŽ. ZAGREB GOD. 22 (2013), BR. 2, STR. $347-366$

BOKULIĆ, M., BOVAN, K. EFEKT NEPOVRATNOGA...
Kanodia, C., Bushman, R. i Dickhaut, J. (1989). Escalation errors and the sunk cost effect: An explanation based on reputation and information asymmetries. Journal of Accounting Research, 27(1), 59-77. doi:10. 2307/2491207

Lala, V. (2005). Too much invested to go back: An investigation of sunk cost effects for monetary and non-monetary resources. (Neobjavljena doktorska disertacija). http://digital.library.okstate.edu/etd/umi-okstate1278.pdf (2. 12. 2011)

Leatherwood, M. L. i Conlon, E. J. (1987). Diffusibility of blame: Effects on persistence in a project. Academy of Management Journal, 30(4), 836-847. doi:10.2307/256165

Moon, H. (2001a). Looking forward and looking back: Integrating completion and sunk-cost effects within an escalation-of-commitment progress decision. Journal of Applied Psychology, 86(1), 104-113. doi:10.1037/0021-9010.86.1.104

Moon, H. (2001b). The two faces of consientiousness: Duty and achievement striving in escalation of commitment dilemmas. Journal of Applied Psychology, 86(3), 533-540. doi:10.1037//0021-9010.86.3.535

Northcraft, G. B. i Wolf, G. (1984). Dollars, sense, and sunk costs: A life cycle model of resource allocation decisions. Academy of Management Review, 9(2), 225-234. doi:10.2307/258436

Prelec, D. i Loewenstein, G. (1998). The red and the black: Mental accounting of savings and debt. Marketing Science, 17(1), 4-28. doi:10. 1287/mksc.17.1.4

Ross, J. i Staw, B. M. (1986). Expo 86: An escalation prototype. Administrative Science Quarterly, 31(2), 274-297. doi:10.2307/2392791

Ross, J. i Staw, B. M. (1993). Organizational escalation and exit: Lessons from the Shoreham nuclear power plant. Academy of Management Journal, 36(4), 701-732. doi:10.2307/256756

Schaubroeck, J. i Williams, S. (1993). Type a behavior pattern and escalating commitment. Journal of Applied Psychology, 78(5), 862-867. doi:10.1037//0021-9010.78.5.862

Schiller, R. J. (2005). Irrational exuberance. New Jersey: Princeton University Press.

Schott, J. P., Scherer, L. D. i Lambert, A. J. (2011). Casualties of war and sunk costs: Implications for attitude change and persuasion. Journal of Experimental Social Psychology, 47(6), 1134-1145. doi:10.1016/ j.jesp.2011.06.002

Simonson, I. i Staw, B. M. (1992). De-escalation strategies: A comparison of techniques for reducing commitment to losing courses of action. Journal of Applied Psychology, 77(4), 419-426. doi:10.1037/00219010.77.4.419

Sivanathan, N., Molden, D. C., Galinsky, A. D. i Ku, G. (2008). The promise and peril of self-affirmation in de-escalation of commitment. Organizational Behavior and Human Decision Processes, 107(1), 1-14. doi:10.1016/j.obhdp.2007.12.004

Soman, D. i Cheema, A. (2001). The effect of windfall gains on the sunk-cost effect. Marketing Letters, 12(1), 51-62. doi:10.1023/A:10081 20003813 
DRUŠ. ISTRAŽ. ZAGREB GOD. 22 (2013), BR. 2, STR. $347-366$

BOKULIĆ, M., BOVAN, K. EFEKT NEPOVRATNOGA...
Soman, D. i Gourville, J. T. (2001). Transaction decoupling: How price bundling affects the decision to consume. Journal of Marketing Research, 38(1), 30-44. doi:10.1509/jmkr.38.1.30.18828

Stanovich, K. E. i West, R. F. (1998). Individual differences in framing and conjunction effects. Thinking \& Reasoning, 4(4), 289-317. doi:10. 1080/135467898394094

Stanovich, K. E. i West, R. F. (2000). Individual differences in reasoning: Implications for the rationality debate? Behavioral and Brain Sciences, 23(5), 645-665. doi:10.1017/S0140525X00003435

Staw, B. M. (1976). Knee-deep in the big muddy: A study of escalating commitment to a chosen course of action. Organizational Behavior and Human Performance, 16(1), 27-44. doi:10.1016/0030-5073(76)90005-2

Staw, B. M. (1981). The escalation of commitment to a course of action. Academy of Management Review, 6(4), 577-587. doi:10.2307/257636

Staw, B. M. (1997). The escalation of commitment: An update and appraisal. U Z. Shapira (Ur.), Organizational decision making (str. 191-215). Cambridge: Cambridge University Press.

Staw, B. M., Barsade, S. G. i Koput, K. W. (1997). Escalation at the credit window: A longitudinal study of bank executives' recognition and write-off of problem loans. Journal of Applied Psychology, 82(1), 130-142. doi:10.1037/0021-9010.82.1.130

Taleb, N. N. (2007). The black swan: The impact of the highly improbable. New York: Random House Trade Paperbacks.

Tang, M. J. (1988). An economic perspective on escalating commitment. Strategic Management Journal, 9(S1), 79-92. doi:10.1002/smj.42 50090709

Thaler, R. (1980). Toward a positive theory of consumer choice. Journal of Economic Behavior \& Organization, 1(1), 39-60. doi:10.1016/ 0167-2681(80)90051-7

Thaler, R. H. (1985). Mental accounting and consumer choice. Marketing Science, 4(3), 199-214. doi:10.1287/mksc.1070.0330

Thaler, R. H. (2004). Mental accounting matters. U C. F. Camerer, G. Loewenstein i M. Rabin (Ur.), Advances in behavioral economics (str. 75-104). Princeton: Princeton University Press.

Whyte, G. (1986). Escalating commitment to a course of action: A reinterpretation. Academy of Management Review, 11(2), 311-321. doi:10. $2307 / 258462$

Whyte, G. (1991). Diffusion of responsibility: Effects on the escalation tendency. Journal of Applied Psychology, 76(3), 408-415. doi:10. 1037/0021-9010.76.3.408

Wiebe, D. J. i Smith, T. W. (1997). Personality and health: Progress and problems in psychosomatics. U R. Hogan, J. Johnson i S. Briggs (Ur.), Handbook of personality psychology (str. 892-908). San Diego: Academic Press.

Zardkoohi, A. (2004). Response: Do real options lead to escalation of commitment? Academy of Management Review, 29(1), 111-119. doi:10. 5465/AMR.2004.11851733 
DRUŠ. ISTRAŽ. ZAGREB GOD. 22 (2013), BR. 2, STR. 347-366

BOKULIĆ, M., BOVAN, K. EFEKT NEPOVRATNOGA..

\section{Sunk Cost Effect}

Marko BOKULIĆ

University of Regensburg, Regensburg

Kosta BOVAN

Zagreb

Normative economic principles, as described in the theory of rational choice, assume that we base our decisions solely on future gains and losses. However, the results of several lines of research show that our decisions are influenced by sunk costs, past investments that are not redeemable. This phenomenon is called the sunk cost effect and it comes in two forms. In choice dilemmas we want to use what we have paid disregarding possible additional costs. When deciding whether to continue an investment, people tend to financially support a failing project. In this paper, both types of sunk cost effects are described and results of relevant research are reviewed, as well as the methodology and criticisms of this research. Furthermore, the differences between economic and psychological theories are considered. In the end, the practical implications of this research for the managerial domain are mentioned.

Keywords: sunk cost effect, choice dilemma, escalation of commitment, judgment and decision making, behavioral economics 